\title{
Delici Kesici Alet Yaralanmalarının Bildirim Sıklığı Neyin Göstergesi?
}

\author{
What Does High Incidence of Sharp Injury Reports Indicate?
}

\author{
Nagehan Didem Sarı, Muzaffer Fincancı, Hürriyet Ferda Soysal, Nurcan Demirkıran*, \\ Suna Koyuncu*, Özden Özgün* \\ S. B. Istanbul Eğitim ve Araştırma Hastanesi, Enfeksiyon Hastalıkları ve Klinik Mikrobiyoloji Bölümü, İstanbul, Türkiye \\ *S. B. Istanbul Eğitim ve Araştırma Hastanesi, Enfeksiyon Kontrol Komitesi, Istanbul, Türkiye
}

\section{Özet}

Amaç: Bu çalışmada hastanemizde son altı yılda sağlık çalışanlarında meydana gelen delici kesici alet yaralanmalarının değerlendirilmesi, personele verilen eğitim uygulamalarının bildirim üzerine olan etkisinin incelenmesi amaçlanmıştır.

Yöntemler: Ocak 2007-Ocak 2013 tarihleri arasında hastanemizde meydana gelen 229 delici kesici alet yaralanması retrospektif olarak değerlendirildi.

Bulgular: Çalışmamızda altı yıllık sürede 229 sağlık çalışanında delici kesici alet yaralanması bildirilmiştir. Bu süre zarfında 1,386 hastane çalışanının eğitim aldığı tespit edilmiştir.

Sonuç: Eğitime katılan personel sayısı arttıkça, maruziyet bildirim sayısının arttığı; çalışanların sürekli eğitimlerinin sağlanmasının, farkındalığı arttırarak personel sağlığının korunmasında hassasiyeti arttıracağı düşünülmüştür. (Haseki Tıp Bülteni 2014; 52: 98-102)

Anahtar Sözcükler: Sağlık çalışanı, yaralanmalar, eğitim
Abstract

Aim: The aim of this study was to evaluate needlestick and sharps injuries in our hospital for the last six years and the effects of education on the prevention of exposure to sharp instruments.

Methods: We retrospectively evaluated sharp injuries occurred in our hospital between January 2007 and January 2013.

Results: It was found that 229 sharp injuries were sustained within six years. During this period, 1.386 health-care workers received education and training on sharps injury prevention.

Conclusion: We concluded that education and training of healthcare workers will increase sharps injury reporting rates and raise awareness and reduce the risk of sharps injuries. (The Medical Bulletin of Haseki 2014; 52: 98-102)

Key Words: Health care workers, injuries, education

Yazışma Adresi/Address for Correspondence: Nagehan Didem Sarı 


\section{Giriş}

Dünya'da 5,6 milyon insan sağlıkla ilişkili işlerde çalışmakta, yılda üç milyon sağlık çalışanı kan ile bulaşan enfeksiyonlara maruz kalmaktadır (1). Bu etkenlerden ilk sırayı virüsler alırken; güncel olarak sıklıkla hepatit B virüsü (HBV), hepatit C virüsü (HCV) ve human immunodeficiency virüs (HIV) bulaşı görülmektedir. Bu enfeksiyon etkenleri ile karşılaşma olasılığı en yüksek olanlar hemşireler, hekimler, yardımcı sağlık personeli ve temizlik personelidir ve gelecekte sağlık çalışanlarının 16,000'inde HCV, 66,000 'inde HBV ve 1000 'inde HIV gelişebileceği tahmin edilmektedir $(2,3)$.

Kontamine kesici-delici tıbbi aletler hem sağlık personeli hem de hastalar için önemli oranda enfeksiyon riski taşır. Kesici delici aletlerin birçoğunun artık tek kullanımlık olması hastalar için riski azaltmışken mesleki maruziyetle enfeksiyon bulaşı devam etmektedir. Bulaşma esas olarak perkütan yol ya da mukozal yolla meydana gelmektedir. Perkütan yolla bulaş; sağlam derinin kesilerek, sivri uçlu aletle, iğnelerle delinerek, yanarak ya da soyularak bütünlüğünün bozulmasılyla gerçekleşirken, burun, göz, oral mukozaya kan ya da vücut sıvılarının teması sonucu mukozal yolla bulaş olmaktadır $(4,5)$.

Temas sonrası enfeksiyonun ortaya çıkısıında; etkenin patojenitesi, temasın tip, maruz kalınan kan miktarı ve kaynak vakanın viral yükü belirleyici olmaktadır (6). HBsAg pozitif bir kişiden yaralanmada enfekte olma olasılığı \%6-\%30 arasında iken, HIV pozitif bir kişiden perkütan yaralanma ile enfekte olma olasılığının \%0,3 olduğu belirlenmiştir. Bistüri, ameliyat dikiş iğnesi ile yaralanmalarda inokülum miktarı azdır. Buna karşılık lümenli iğneler, kateterler ile yaralanmalarda bulaş riski yüksektir. HBV'nin 108-1010 partikül/mL kan ile bulaş oranı \%5-\%30; HCV'nin 10-104 partikül/mL kan ile bulaş oranı \%1,8 (\%0-\%7); HIV'in 10-104 partikül/mL kan ile bulaş oranı \%0,3 $(0-0,9)$ olarak belirlenmiştir (2).

Bu çalışmada amacımız, hastanemizde meydana gelen delici kesici alet yaralanmalarını değerlendirerek, bildirim sıklığına etki eden faktörleri belirlemektir.

\section{Yöntemler}

Ocak 2007-Ocak 2013 tarihleri arasında İstanbul Eğitim ve Araştırma Hastanesi çalışanlarında delici kesici aletle meydana gelen vakaların kaydedildiği, Enfeksiyon Kontrol Komitesi (EKK) tarafından düzenlenmiş olan formlar ve hastanemiz bilgisayar sisteminindeki kayıtlar, hastanemiz eğitim hemşireleri ve enfeksiyon kontrol hemşirelerinin aynı tarihler arasında düzenlemiş olduğu konuyla ilgili eğitime katıım kayıtları retrospektif olarak incelenmiş, 229 vakanın meslek grupları, yaralanma şekilleri, maruziyet esnasında kullandıkları koruyucu yöntemler, HBV'ye karşı immunizasyonları, kaynağın bilinmesi, düzenlenen eğitimlere katılan personel sayısı incelenmiştir. Elde edilen veriler Microsoft excell programında değerlendirilerek yüzde ve frekans oranları belirlenmiş̧ir. Hastanemizde uygulanan protokol Tablo 1'de sunulmuştur.

\section{Bulgular}

Hastanemizde belirlenen tarihler arasında delici kesici aletle yaralanan 229 sağlık çalışanı çalışmaya dahil edilmiştir. Personelin \%58'i kadın, \%42'si erkekti. Meslek gruplarına göre incelendiğinde 97'si hemşire (\%42), $78^{\prime} i$ temizlik personeli (\%34), 28'i hekim (\%12) ve 26 'sının yardımcı sağlık personeli (\%12) olduğu görüldü. Hastanemizde kesici delici alet yaralanmalarının meslek ve yıllara göre dağılımı Grafik 1'de gösterilmiştir.

Yardımcı sağlık görevlisi olarak ayrılan grupta 26 kişi tespit edildi, laborant $(\% 15)$, anestezi $(\% 11,5)$ ve radyoloji (\%10) teknisyeninin yanı sıra görevleri gereği delici kesici alet yaralanmasına maruz kalabileceği ön görülmeyen dört tıbbi sekreterin ve üç güvenlik görevlisinin de (\%3) yaralandığı görüldü.

Olguların 26'sı (\%11) mukoza teması, 203'ü (\%89) perkütan yaralanma şeklinde meydana gelmişti. Yaralanma şeklinin meslek gruplarına göre dağılımı Grafik 2'de özetlenmiştir.

Yaralanmaya maruz kalan personelin olay anında \%79'u eldiven, \%19'u önlük, \%11'i maske, \%7'si gözlük kullanmaktaydı ve \%75,5'i hepatit B virüsüne karşı aşılı, \%6'sı doğal bağışıktı. Tüm maruziyetlerden 33 çalışanın HBV'ye karşı immunizasyonu olmadığı tespit edildi. Vakaların 105'inin kaynağı belli olup 20'si (\%19) HBsAg pozitif, 13'ü (\%12) anti HCV pozitif, dördü (\%4) anti HIV pozitifti. HBsAg pozitif hasta ile teması olan dört çalışanın HBV'ye karşı immunizasyonu olmadığından 24 saat içinde hepatit $B$ immunglobulini $(0,06 \mathrm{ml} / \mathrm{kg})$ ve eş zamanlı hepatit B aşısı yapıldı. Illk aşıdan sonraki bir ve altıncı aylarda olgulara rapel dozlar yapılarak immunizasyon sağlandı.

Anti HIV pozitif kaynakla temas eden dört kişiye bir ay süreyle antiretroviral (lopinavir+ritonavir $2 \times 400 \mathrm{mg}$, lamuvidin 2×150 mg, zidovudin $2 \times 300 \mathrm{mg}$ ) profilaksi uygulanmıştı. Anti HCV pozitif kaynakla temas eden 13 personel takip edildi. Personelin altı aylık takiplerinin hiç birinde HBsAg, Anti HCV ve Anti HIV pozitifliği gelişmedi.

Hastanemizde 2007 yllından itibaren düzenli olarak Enfeksiyon kontrolü ve kesici delici alet yaralanmaları ile ilgili hastanede göreve başlamadan oryantasyon programı içinde ve yılda iki defada kalite hizmet standartlarını geliştirme programı dahilinde ortalama üç saat eğitim verilmektedir. Uygulanan program Enfeksiyon Kontrol Hemşireleri ve Enfeksiyon Uzmanları tarafından yürütülmekte olup, tıbbi atık yönetimi, el hijyeni ve delici kesici alet yaralanmaları ve maruziyet halinde uygulanacak protokol anlatılmaktadır. Kayıtlar incelendiğinde eğitimlere 
Tablo 1. Kontamine delici-kesici alet yaralanmasına maruz kalan personelin takip prosedürü

\begin{tabular}{|c|c|c|c|c|c|}
\hline \multirow{2}{*}{$\begin{array}{l}\text { Kaynak } \\
\text { Hastanın } \\
\text { Test sonuçları }\end{array}$} & \multicolumn{4}{|c|}{ Personel Takip Yaklaşımı } & \multirow{2}{*}{$\begin{array}{l}\text { Tedavi } \\
\text { Hemen }\end{array}$} \\
\hline & Hemen & $\begin{array}{l}6 \text { Hafta } \\
\text { Sonra }\end{array}$ & $\begin{array}{l}12 \text { Hafta } \\
\text { Sonra }\end{array}$ & 6 Ay Sonra & \\
\hline Anti-HIV + & Anti HIV & Anti HIV & Anti HIV & Anti HIV & $\begin{array}{l}\text { Kaletra+Combivir } 28 \text { gün } \\
\text { süre ile }\end{array}$ \\
\hline \multirow{2}{*}{$\mathrm{HBsAg}+$} & Anti HBs (-) & - & - & - & $\begin{array}{l}\text { HBlg } 0,06 \mathrm{ml} / \mathrm{kg}(\mathrm{IM}) \\
\text { Hepatit B Aşıs başlanır. } \\
\text { (0.-1.-6. aylarda) Aşılama } \\
\text { bittikten sonra Anti HBs } \\
\text { kontrolü }\end{array}$ \\
\hline & Anti HBs (+) & - & - & - & Tedaviye gerek yoktur \\
\hline \multirow{2}{*}{ Anti HCV } & \multirow{2}{*}{$\begin{array}{l}\text { Anti HCV } \\
\text { ALT }\end{array}$} & \multirow{2}{*}{$\begin{array}{l}\text { Anti HCV } \\
\text { HCV RNA }\end{array}$} & $\begin{array}{l}\text { Anti HCV } \\
\text { HCV RNA (-) }\end{array}$ & $\begin{array}{l}\text { Anti HCV } \\
\text { ALT }\end{array}$ & $\begin{array}{l}\text { Anti HCV (+) ise Kr. Hepa- } \\
\text { tit polk.'ne } \\
\text { yönlendirilir. }\end{array}$ \\
\hline & & & $\begin{array}{l}\text { Anti HCV } \\
\text { HCV RNA (+) }\end{array}$ & - & $\begin{array}{l}\text { Kr. Hepatit polk.'ne } \\
\text { yönlendirilir. }\end{array}$ \\
\hline $\begin{array}{l}\text { Kaynak } \\
\text { bilinmiyorsa } \\
\text { veya kaynağın } \\
\text { hastalık durumu } \\
\text { bilinmiyorsa }\end{array}$ & $\begin{array}{l}\text { HBs Ag } \\
\text { Anti HIV } \\
\text { Anti HBs } \\
\text { Anti HCV, } \\
\text { ALT }\end{array}$ & $\begin{array}{l}\text { Anti HIV } \\
\text { Anti HCV }\end{array}$ & $\begin{array}{l}\text { Anti HIV } \\
\text { Anti HCV }\end{array}$ & Anti HCV & $\begin{array}{l}{ }^{*} \text { Aşısız personele } \\
\text { Hepatit B aşısı } \\
\text { (0-1-6.aylarda) başlanır. } \\
\text { *HIV-HCV-HBV } \\
\text { enfeksiyonları için test } \\
\text { sonuçlarına göre } \\
\text { yukarıdaki gibi } \\
\text { yaklaşılır. }\end{array}$ \\
\hline
\end{tabular}

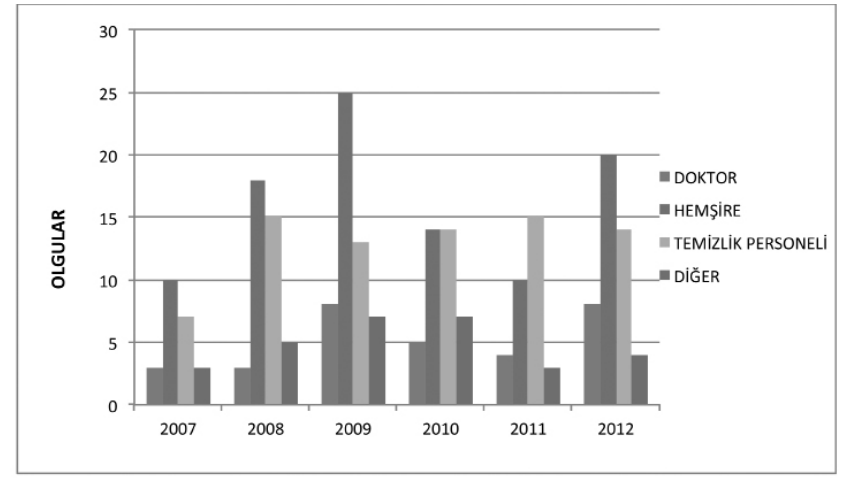

Grafik 1. Hastanemizde delici- kesici alet yaralanmalarının yıllarameslek gruplarına göre dağılımı

katılan personel sayısının, maruziyet bildirim sayısıyla ilişkili olduğu, eğitime katılım sayısının yüksek olduğu senelerde bildirim oranının arttığı görüldü. Eğitime katılan personel sayısının, bildirilen maruziyet olgularının karşılaştırılması Grafik 3'te değerlendirilmiştir.

\section{Tartışma}

Delici kesici alet yaralanmasına maruz kalan personelin kayıtları 2006'dan itibaren tutulmakta, Ocak 2008'den itibaren de standart bir formla bildiriler kaydedilmektedir.

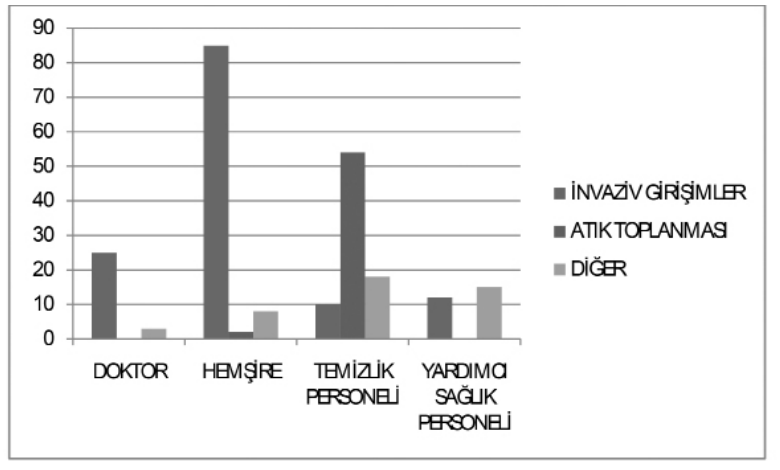

Grafik 2. Delici-kesici alet yaralanma şeklinin meslek gruplarına göre dağılımı

Altı yıllık süre zarfında 229 sağlık personelinin enfeksiyon kontrol hemşirelerine başvurduğu, bildirim yapanların \%58'inin kadın olduğu ve meslek grupları irdelendiğinde çoğunun hemşire ve temizlik görevlisi olduğu dikkati çekmiştir. Konuyla ilgili yapılan çalışmaların çoğunda maruziyette hemşire grubu ilk sırada yer aldığı bilinmektedir (7). Ancak Merih ve ark.'nın yaptığı çalışmada \%72 temizlik görevlilerinin, Gücük ve ark.'nın çalışmasında ise \%56 ile doktorların ilk sırada olduğu tespit edilmiştir $(8,9)$. Yaralanma şekilleri incelendiğinde; \%61 enjektör iğnesiyle olan perkütan 


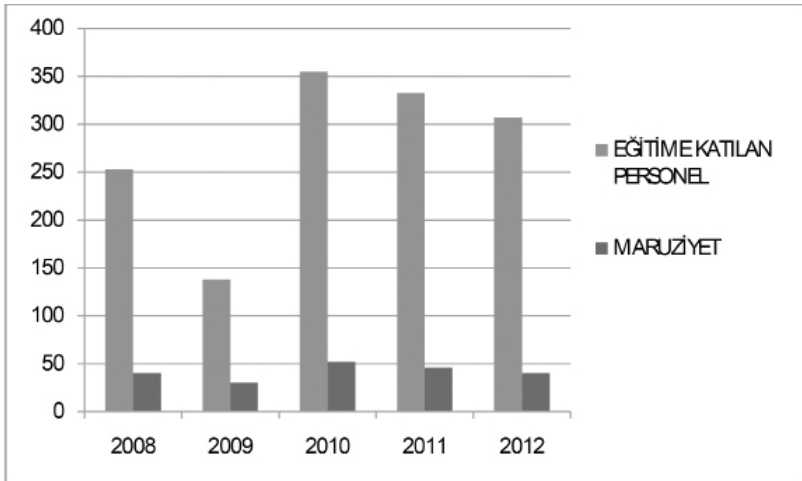

Grafik 3. Eğitime katılan personel sayısının maruziyet bildirim sayısı ile olan ilişkisi

yaralanmalar ilk sırada yer almaktaydı. Yaralanma şekillerinin incelendiği Kaya ve ark.'nın çalışmasında yaralanmaların \%51 enjektör kapağı kapatılırken, \%18 damar yolu açarken, \%16 tıbbı atıklar bertaraf edilirken olduğu belirtilmiştir (10). Bizim çalışmamızda penatran yaralanmaların alt grupları ayrılamamıştır. Yapılan çalışmalarda \%36 ile \%81 oranında enjektör kapağı kapatma alışkanlığı olduğu bildirilmiştir (11-13).

Hem hemşire hem de hekim grubunda penetran yaralanmalar ilk sırada görülmüştür. Hekimlere ait yapılan bildirimlerden \%68'inin cerrahi dal hekimi olduğu tespit edildi. Bu konuda yapılan araştırmalarda da cerrahların en sık dikiş atarken yaralandığı, bunun cerrahi teknikle ilişkili olduğu belirtilmiş; bu maruziyetin engellenmesi için cerrahın dikiş atarken ya da keserken dokuyu alet yardımı ile tutması ve aynı bölgede iki cerrahın aynı anda çalışmaması önerilmiştir. Ameliyat esnasında aletlerin elden ele geçirilmemesi ve aletlerin alıp verilirken konabileceği güvenli alan oluşturulması gerektiği bildirilmiş̧ir $(14,15)$. Incelememizde hekim grubunun maruziyetlerini düzenli olarak bildirmediği, hepatit B immunizasyonu uygulanmış olanların, diğer kan yolu ile geçen hastalıkları yeteri kadar önemsemediği ve bildirim yapmadıkları anlaşı Imıştır.

Temizlik görevlilerinin maruziyetinin temizlik işlemi sırasında uygun şekilde delici kesici aletleri ortamdan uzaklaştırmaması nedeniyle olduğu görülmüştür. "Centers for Disease Control and Prevention" (CDC) 1982 yllında ilk defa enfeksiyondan korunabilmek için standart önlemleri gündeme getirmiş, ilerleyen yıllarda bu öneriler güncellenmiştir. Bu önerilere göre tüm hastalar ve kan örnekleri enfekte kabul edilmeli, sağlık çalışanları bu standartlara göre hareket etmelilerdir (12). Lateks eldivenleri iyi bir bariyer oluşturduğu için eldivenin üstünden oluşan yaralanmada enfekte olma olasılığının düşük olduğu bildirilmiş olup, lümensiz iğnenin lateks eldivenden geçerken inokulum miktarını 10-100 kat azalttığı görülmüştür (16). Yaralanmaya maruz kalan personelin, maruziyet esnasında kullandığı koruyucu önlemler incelendiğinde; \%21'inin hiçbir koruyucu önlem almadığı, \%60'ının sadece eldiven kullandığı, \%11'nin eldiven ve önlüğü birlikte kullandığı, \%8'inin eldiven, maske ve önlüğü birlikte kullandığı görülmüştür. En çok kullanılan bariyer önlemi \%79 ile eldiven olmuş ve \%7 gözlük kullanımı tespit edilmiştir. Sağlık çalışanları koruyucu önlemleri kullanma oranlarının değerlendirildiği Beltrami ve ark.'nın çalışmasında \%52'sinin eldiven kullandığı, \%5'inin maske taktığı, \%4'ünün önlük giydiği ve \%2'sinin gözlük kullandığı görülmüştür (2). Bu konuda yapılmış farklı çalışmalarda da koruyucu önlem alma oranları \%55-\%68 arasında değişmekte ve en sık kullanılan önlemin eldiven olduğu görülmektedir $(8,10,12)$.

Literatürle olan karşılaştırmalarımızda yayınlarda olanlarla benzer sayılara ulaştığımız görülmüştür.

Hastanemizin kalite hizmet standartları çerçevesinde düzenlemiş olduğu eğitim programı yıllar içinde revize edilmekle beraber 2007 yılından itibaren sürdürülmektedir. Hastaneye başlayan her personel başlama işlemlerinin yapıldığı esnada Enfeksiyon Kontrol Hemşireleri ve Enfeksiyon Hastalıkları Uzmanı tarafından delici kesici alet yaralanmaları ve maruziyet sonrası yapılacak işlemler, hastane enfeksiyonları ve el hijyeni, atık yönetimi üzerine bir anket uygulanarak eksik noktalar bire bir anlatılarak bilgi eksikliği giderilmektedir.

Ancak yapmış olduğumuz bu eğitimin sözel olması, görsellerin olmayışı, kişinin eğitime hazır olmaması ve bu bire bir eğitimin bir defa kişinin hastaneye başlayışı esnasında yapılması nedeniyle tek başına yeterli olmadığı düşünülmektedir.

Yapmış olduğumuz çalışmada yıllık düzenlenen oryantasyon eğitimine katılan personel sayısının artışılla bildirim sıklığının artısııın paralelliği, eğitim sıklı̆̆ını arttırmamı ve yılda iki kere olacak şekilde tüm hastanede çalışan sağlık personeline uygulanmasının planlanmasına yol açmışır.

\section{Kaynaklar}

1. Prüss-Ustün A1, Rapiti E, Hutin Y. Estimation of the global burden of diseases attributable to contaminated sharps injuries among healthcare workers. Am J Ind Med 2005;48:482-90.

2. Beltrami EM1, Williams IT, Shapiro CN, Chamberland ME. Chamberland ME.Risk and management of bloodborne infections in health care workers .Clin Microbiol Rev 2000;13:385-407.

3. Centers for Disease Control (CDC). Guidelines for prevention of transmission of human immunodeficiency virus and hepatit-B virusto Health-Care and Public-Safety Workers. MMWR Morb Mortal Wkly Rep 1989;38 Suppl 6:1-37.

4. Moloughney BW. Transmission and postexposure management of bloodborne virus infections in the health care setting: where are now? CMAJ 2001;165:445-51.

5. European Centre for Disease Prevention and control (ECDC). Hepatitis B and C in the EU neighbourhood: prevalence, burden of disease and screening policies. Semtember 2010. 
6. Bolyard EA, Tablan OC, Williams WW, Pearson ML, Shapiro CN Deitchmann SD. Guideline for infection control in healthcare personnel, 1998. Hospital Infection Control Practices Advisory Committee. Infect Control Hosp Epidemiol 1998;19:407-63.

7. Kaya Ş, Baysal B, Eşkazan AE, Çolak H. Diyarbakır Eğitim Araştırma Hastanesi Sağlık Çalışanlarında Kesici Delici Alet Yaralanmalarının Değerlendirilmesi. Vir Hep Derg 2012;18:107-10.

8. Merih YD, Kocabey MY, Çırpı F, Bolca Z, Celayir AR. Bir devlet Hastanesinde 3 Yıl icçerisinde Görülen Kesici-Delic Alet Yaralanmalarının Epidemiyolojisi ve Korunmaya Yönelik Önlemler. Zeynep Kamil Tıp Bülteni. Cilt 40, 2009; Sayı:1 (115).

9. İnanç N, Özkan Ö. Hemşirelerin kesici-delici-batıcı cisim yaralanma sıklığı ve aldıkları önlemlerin incelenmesi. V. Ulusal Hemşirelik Kongresi Kitabı1997;222-36.

10. Gücük M, Karabey S, Yolsay N, Özden YI. İstanbul Tıp Fakültesi Genel Cerrahi Kliniği Çalışanlarında Kesici-Delici Ale Yaralanmaları. Hastane Infeksiyonları Dergisi 2002;6:72-81.
11. Doğan F. Hemşirelerde iğne batma sıklığı ve nedenleri. Yüksek Lisans Tezi. İstanbul, 1998.

12. US Public Health Service .UpdatedUS, Public Health Service Guidelines fort he management of Occupational Exposures to HBV, HVC, and HIV and recommendations for postexposue prophylaxis. MMWR Recomm Rep 2001;50:1-52.

13. Kuruüzüm Z, Elmalı Z, GünayS, Gündüz Ş, Yapan Z. Sağlık Çalışanlarında Kan ve Beden Sıvılarıyla Oluşan Mesleksel Yaralanmalar: Bir anket çalışması. Mikrobiyoloji Bül 2008;42:61-9.

14. Raahave D, Bremmelgaard A. New operative technique to reduce surgeons risk of HIV infection. J Hosp Infect 1991;18(suppl)177-83.

15. Beltrami EM1, McArthur MA, McGeer A, et al. The nature and frequency of bloodcontacts among home healthcare workers. Infect Control Hosp Epidemiol 2000;21:765-70.

16. Heptonstall J,Turnbull S, Henderson D, Harling K, Scott G. Sharps injury:A review of contraversial areas in the managament of sharps accidents. J Hosp Infect 1999;43(Suppl):219-23. 